\title{
THE IMPACT OF FISCAL POLICY ON GROSS DOMESTIC PRODUCT IN THE EUROPEAN UNION. A PANEL VAR MODEL APROACH
}

\author{
Ioan Talpoş ${ }^{1}$ \\ Alexandru Avram ${ }^{2}$ \\ Roxana Heteş ${ }^{3}$
}

\begin{abstract}
In our research, we intend to observe the influence of fiscal policy together with the interest rate and inflation rate on economic growth in the European Union member states. Therefore, our goal is to identify the impact of the main instruments of fiscal policy, using an unrestricted panel VAR model, on the evolution of GDP. In this way we can understand what is the response of the GDP of the member states of EU 27 to the evolution of public debt, government deficit, government spending, interest rate and inflation. Using impulse response functions we have seen that private consumption has a positive influence on GDP, the rise in public debt has a negative influence on the evolution of GDP, government expenditure has an alternating influence that turns from positive in the first half of the observation period into negative in the second, the interest rate has a strong negative influence while the inflation rate has a positive influence on the evolution of GDP.
\end{abstract}

Keywords: monetary policy, fiscal policy, economic growth

JEL Code: E63

\section{Introduction}

Due to the financial and economic crisis that started in 2007, and covered most of the EU member states, fiscal and monetary authorities have tried to counter the effects of the crisis by various measures, but all concluded in the rising of public debt and government deficit. Our researched focused on the effects of these variables, relating to fiscal policy instruments and also inflation and interest rate, as part of monetary policy variables. After using the impulse response functions we have identified the influence of these variables on GDP.

In this regard, we used the annual data specific for each member state in the EU 27, taken from Eurostat reports, grouped in a panel type model, the variables being related to each member state for the study period 2000 - 2011. The variables included in our study are: gross domestic product, private consumption, government debt, gross fixed capital formation, inflation, interest rate at 12 months and government consumption.

After using the impulse function specific for the Autoregressive Vector (VAR) model, we identified the effects of some components of fiscal policy in the European Union over the size of GDP. The observations span along a 12 years period, totaling 324 observations that we considered sufficient to express an opinion on the influence of monetary and fiscal policy instruments on gross domestic product, private consumption and investment.

\footnotetext{
${ }^{1}$ West University of Timisoara, Romania,e-mail: ioan.talpos@gmail.com

${ }^{2}$ West University of Timisoara, Romania, e-mail: alexlavram@gmail.com

${ }^{3}$ West University of Timisoara, Romania,e-mail: rhetes@yahoo.com
} 
The paper was structured using the literature review section, research methodology, results and discussion and conclusions. Therefore, in the literature review section we have presented the main studies that were taken into consideration and their main results were summarized in Table no. 1. In the second section - research methodology we have presented our approach based on an unrestricted VAR, where we have analyzed the impact of private consumption, gross fixed capital formation, public debt, government spending, interest rate and inflation rate. The results obtained in our article are presented in the Results and discussion sections of the paper. The main findings are summarized in Table no. 7.

\section{Literature review}

In our research, we have started from studies that have imposed themselves as being defining for the issues addressed in topic of fiscal policy instruments, interest rate and inflation rate. Therefore, Blachard and Perotti (2002), Gali (2006), Fatas and Mihov (2001), Biau and Girard (2005), Favero and Giavazzi (2007) are all important papers that most of the studies made under VAR methodology have started from.

Perotti (2002) used an Autoregressive Vector with five variables, including GDP, GDP deflator, government consumption, net income and interest rate. Gali (2006) used an Autoregressive Vector model with 4 variables including GDP, government consumption, employment and interest rate. Biau and Girard (2005) have studied the impact of fiscal policy on economic growth in France, by using an Autoregressive Vector model with five variables taking into account government consumption, net income, interest rate, prices and GDP. Their results have shown that fiscal policy has a positive impact on consumption and investment but only for the first year.

Baum and Koesner (2011), continuing from the study of Blanchard and Perotti, have concluded that fiscal steering of the economy should be made in times of positive output gap while discretionary spending in order to encourage the economy should be made only in times of negative output gap.

The variables used in studies mentioned above, together with main results of the studies above can be summarized in the following table, offering us a more schematic view on the research topic we have addressed:

Table no. 1 .

Results of various research performed on fiscal policy implications on economic growth

\begin{tabular}{|l|l|l|l|}
\hline \multicolumn{1}{|c|}{ Authors } & \multicolumn{1}{|c|}{$\begin{array}{c}\text { Year of } \\
\text { publication }\end{array}$} & \multicolumn{1}{c|}{ Variables used } & \multicolumn{1}{c|}{ Results } \\
\hline $\begin{array}{l}\text { Blachard, } \\
\text { Perotti }\end{array}$ & 2002 & $\begin{array}{l}\text { GDP; Gdp deflator; } \\
\text { Government } \\
\text { consumption; } \\
\text { Net income Interest rate; } \\
\text { Investments. }\end{array}$ & $\begin{array}{l}\text { Government consumption has a } \\
\text { positive influence on GDP but } \\
\text { not on invetments. }\end{array}$ \\
\hline Biau, Girard & 2005 & $\begin{array}{l}\text { GDP; } \\
\text { Government } \\
\text { consumption; } \\
\text { Net incone; } \\
\text { HICP; } \\
\text { Interest rate; } \\
\text { Investments. }\end{array}$ & $\begin{array}{l}\text { Fiscal policy has a positive } \\
\text { influence on consumption and } \\
\text { investments, but only for the first } \\
\text { year. }\end{array}$ \\
\hline Gali & 2006 & $\begin{array}{l}\text { GDP; } \\
\text { Government } \\
\text { consumption; }\end{array}$ & $\begin{array}{l}\text { Government consumption has a } \\
\text { positive influence on private } \\
\text { consumption and on GDP but not }\end{array}$ \\
\hline
\end{tabular}




\begin{tabular}{|c|c|c|c|}
\hline & & $\begin{array}{l}\text { Private consumption; } \\
\text { Labor; } \\
\text { Interest rate; } \\
\text { Investments. }\end{array}$ & on investments. \\
\hline $\begin{array}{l}\text { Beetsma, } \\
\text { Giuliodori, } \\
\text { Klaassen }\end{array}$ & 2006 & $\begin{array}{l}\text { GDP; } \\
\text { Government } \\
\text { consumption; } \\
\text { Private consumption; }\end{array}$ & $\begin{array}{l}\text { Government consumption has a } \\
\text { negative influence } \\
\text { consumption and on GDP. }\end{array}$ \\
\hline $\begin{array}{l}\text { Favero, } \\
\text { Giavazi }\end{array}$ & 2007 & $\begin{array}{l}\text { GDP; } \\
\text { Public debt; } \\
\text { Level of taxes; } \\
\text { Cost of public debt. }\end{array}$ & $\begin{array}{l}\text { Government consumption and } \\
\text { public debt have a negative } \\
\text { influence on consumption and on } \\
\text { GDP. } \\
\text { Also, the cost of public debt has a } \\
\text { strong negative influence on } \\
\text { GDP. }\end{array}$ \\
\hline Afonso, Sousa & 2009 & $\begin{array}{l}\text { GDP; } \\
\text { Government } \\
\text { expenditure; } \\
\text { Government revenues; } \\
\text { Private consumption; } \\
\text { Private investments; } \\
\text { Inflation rate; } \\
\text { Government debt; } \\
\text { Labour productivity. }\end{array}$ & $\begin{array}{l}\text { Government expenditure have a } \\
\text { relative low impact on the } \\
\text { evolution of GDP; } \\
\text { Government expenditure have a } \\
\text { negative impact on investments; }\end{array}$ \\
\hline
\end{tabular}

\section{Research Methodology}

Using Cholesky impulse - response functions we want to show the influence of exogenous variables on the evolution of GDP. The variables used in this study are: GDP, private consumption, government debt, gross fixed capital formation, inflation, interest rates at 12 months and government consumption. Data were taken from the Eurostat website, which are seasonally adjusted, being differentiated at first degree and logarithmically, exception making interest rate and inflation. The ordering in Cholesky methodology was thought to be as closer to the GDP additive formula thus having the first independent variable as GDP (-1) followed by private consumption, government spending, government debt, gross fixed capital consumption, inflation and interest rate.

The main limitation in our study is that the research is focusing on the short run impact of the variables described above on GDP and not on the long run. Even so, we consider our results worth mentioning since they are accordingly to the literature review described above.

The VAR model used in this study is an unrestricted VAR, since the variables are integrals of different degrees, as shown in Table 2. This approach was recommended by Harvey, since 1990, because he was aware of the issues raised by the use of variables I (0) and I (1) in the same model. The number of Lags chosen is 2 as shown in Table no. 3.

From table no. 4 it can be seen that in this case the VAR satisfies the stability condition.

$$
\begin{aligned}
& Y_{1, t}=\alpha_{1}+\Delta \sum_{j=1}^{k} \beta_{1, j} Y_{1, t-j}+\Delta \sum_{j=1}^{k} \delta_{1, j} C_{1, t-j}+\Delta \sum_{j=1}^{k} \varepsilon_{1, j} G_{1, t-j}+\Delta \sum_{j=1}^{k} \theta_{1, j} D_{1, t-j}+\Delta \sum_{j=1}^{k} \mu_{1, j} I_{1, t-j} \\
& +\Delta \sum_{j=1}^{k} \pi_{1, j} p_{1, t-j}+\Delta \sum_{j=1}^{k} \sigma_{1, j} i_{1, t-j}+u 1_{t}
\end{aligned}
$$


where:

$Y=\mathrm{GDP}$;

$C=$ private consumption;

$G=$ government consumption;

$D=$ government debt;

$I=$ gross fixed capital formation;

$p=$ inflation;

$i=$ interest rate at 12 months;

$C_{1, t}=\alpha_{2}+\Delta \sum_{j=1}^{k} \beta_{2, j} Y_{1, t-j}+\Delta \sum_{j=1}^{k} \delta_{2, j} C_{1, t-j}+\Delta \sum_{j=1}^{k} \varepsilon_{2, j} G_{1, t-j}+\Delta \sum_{j=1}^{k} \theta_{2, j} D_{1, t-j}+\Delta \sum_{j=1}^{k} \mu_{2, j} I_{1, t-j}$

$+\Delta \sum_{j=1}^{k} \pi_{2, j} p_{1, t-j}+\Delta \sum_{j=1}^{k} \sigma_{2, j} i_{1, t-j}+u 2_{t}$

$G_{1, t}=\alpha_{3}+\Delta \sum_{j=1}^{k} \beta_{3, j} Y_{1, t-j}+\Delta \sum_{j=1}^{k} \delta_{3, j} C_{1, t-j}+\Delta \sum_{j=1}^{k} \varepsilon_{3, j} G_{1, t-j}+\Delta \sum_{j=1}^{k} \theta_{3, j} D_{1, t-j}+\Delta \sum_{j=1}^{k} \mu_{3, j} I_{1, t-j}$

$+\Delta \sum_{j=1}^{k} \pi_{3, j} p_{1, t-j}+\Delta \sum_{j=1}^{k} \sigma_{3, j} i_{1, t-j}+u 3_{t}$

$$
\begin{aligned}
& D_{1, t}=\alpha_{4}+\Delta \sum_{j=1}^{k} \beta_{4, j} Y_{1, t-j}+\Delta \sum_{j=1}^{k} \delta_{4, j} C_{1, t-j}+\Delta \sum_{j=1}^{k} \varepsilon_{4, j} G_{1, t-j}+\Delta \sum_{j=1}^{k} \theta_{4, j} D_{1, t-j}+\Delta \sum_{j=1}^{k} \mu_{4, j} I_{1, t-j} \\
& +\Delta \sum_{j=1}^{k} \pi_{4, j} p_{1, t-j}+\Delta \sum_{j=1}^{k} \sigma_{4, j} i_{1, t-j}+u 4_{t}
\end{aligned}
$$

$$
\begin{aligned}
& I_{1, t}=\alpha_{5}+\Delta \sum_{k=1}^{k} \delta_{5_{r} j} Y_{1, t-j}+\Delta \sum_{k=1}^{k} \varepsilon_{5, j} C_{1, t-j}+\Delta \sum_{k=1}^{k} \theta_{5_{r} j} G_{1, t-j}+\Delta \sum_{k=1}^{k} \mu_{5, j} D_{1, t-j}+ \\
& \sum_{k=1}^{k} \pi_{5, j} p_{1, t-j}+\Delta \sum_{k=1}^{k} \sigma_{5, j} i_{1, t-j}+u 5_{t}
\end{aligned}
$$

After estimating the VAR's value, we have analyzed through an impulse function the response of the variables taken into account on GDP. 
Testing series by Augmented Dickey Fuller and Philips Perron Pesaran Test

Table no. 2

\begin{tabular}{|c|c|c|c|c|c|c|c|}
\hline \multirow[t]{2}{*}{ Variable } & \multirow[t]{2}{*}{ Results } & \multirow{2}{*}{$\begin{array}{l}\begin{array}{l}\text { Cross } \\
\text { sections }\end{array} \\
\text { Coefficient }\end{array}$} & \multirow{2}{*}{$\begin{array}{l}\text { First degree difference } \\
\text { Probability }\end{array}$} & \multirow[t]{2}{*}{\begin{tabular}{|l|} 
Integration \\
order
\end{tabular}} & & & \\
\hline & & & & & Coefficient & Probability & \\
\hline \multirow{3}{*}{ L_PIB } & Im, Pesaran and Shin W-stat & 1.29448 & 0.9023 & \multirow{21}{*}{27} & -2.17108 & $0.015^{*}$ & \multirow{3}{*}{$\mathrm{I}$} \\
\hline & ADF - Fisher Chi-square & 34.2145 & 0.9837 & & 76.1948 & 0.025 & \\
\hline & PP - Fisher Chi-square & 74.6276 & 0.0329 & & 103.958 & 0.0001 & \\
\hline \multirow{3}{*}{ L_Cons } & Im, Pesaran and Shin W-stat & -2.22971 & $0.0129 *$ & & -5.10899 & 0 & \multirow{3}{*}{0} \\
\hline & ADF - Fisher Chi-square & 76.7529 & 0.0226 & & 127.049 & 0 & \\
\hline & PP - Fisher Chi-square & 118.984 & 0 & & 327.888 & 0 & \\
\hline \multirow{3}{*}{ L_GFCF } & Im, Pesaran and Shin W-stat & -0.00662 & 0.4974 & & -2.78638 & $0.0027 *$ & \multirow{3}{*}{$\mathrm{I}$} \\
\hline & ADF - Fisher Chi-square & 45.8691 & 0.7765 & & 86.6936 & 0.0032 & \\
\hline & PP - Fisher Chi-square & 36.6882 & 0.9657 & & 86.638 & 0.0032 & \\
\hline \multirow{3}{*}{ L_Govexp } & Im, Pesaran and Shin W-stat & 0.95965 & 0.8314 & & -2.50915 & $0.0061 *$ & \multirow{6}{*}{0} \\
\hline & ADF - Fisher Chi-square & 44.2297 & 0.826 & & 85.7054 & 0.0039 & \\
\hline & PP - Fisher Chi-square & 97.0951 & 0.0003 & & 174.381 & 0 & \\
\hline \multirow{3}{*}{ Inflation } & Im, Pesaran and Shin W-stat & -6.49471 & $0 *$ & & -9.47824 & 0 & \\
\hline & ADF - Fisher Chi-square & 141.421 & 0 & & 197.725 & 0 & \\
\hline & PP - Fisher Chi-square & 250.161 & 0 & & 372.974 & 0 & \\
\hline \multirow{3}{*}{$\operatorname{Rd} 12$} & Im, Pesaran and Shin W-stat & -5.43937 & $0 *$ & & -3.40151 & 0.0003 & \multirow{3}{*}{0} \\
\hline & ADF - Fisher Chi-square & 121.936 & 0 & & 92.9894 & 0.0008 & \\
\hline & PP - Fisher Chi-square & 106.58 & 0 & & 135.103 & 0 & \\
\hline \multirow{3}{*}{ L_Govdebt } & Im, Pesaran and Shin W-stat & 6.89912 & 1 & & -2.11858 & $0.0171 *$ & \multirow{3}{*}{ I } \\
\hline & ADF - Fisher Chi-square & 22.0336 & 1 & & 78.0207 & 0.0179 & \\
\hline & PP - Fisher Chi-square & 19.7352 & 1 & & 123.744 & 0 & \\
\hline
\end{tabular}

* Significance 1\%, ** Significance 5\%, *** Significance 10\% 
In Table no. 3, we have identified the optimal number of lags that should be selected. In this sense, the optimal number of lags was two, as shown in Table 3, having three criteria confirmed out of 5 , which is the maximum of the six lags considered when estimated the VAR.

\section{Selection of lags' number}

\begin{tabular}{|l|l|l|l|l|l|l|}
\hline Lag & LogL & LR & FPE & AIC & SC & HQ \\
\hline \hline \multicolumn{7}{|l|}{} \\
\hline \hline 0 & -932.983 & NA & $1.82 \mathrm{E}-05$ & 8.952215 & 9.063786 & 8.997319 \\
\hline 1 & 880.3419 & 3488.491 & $9.19 \mathrm{E}-13$ & -7.850875 & $-6.958313^{*}$ & -7.490045 \\
\hline $\mathbf{2}$ & 973.8996 & 173.75 & $\mathbf{6 . 0 2 e}-13 *$ & $\mathbf{- 8 . 2 7 5 2 3 4} *$ & -6.60168 & $\mathbf{- 7 . 5 9 8 6 7 8 *}$ \\
\hline 3 & 1020.376 & 83.21572 & $6.19 \mathrm{E}-13$ & -8.251204 & -5.796659 & -7.258922 \\
\hline 4 & 687.9029 & 99.59293 & $1.35 \mathrm{E}-12$ & -7.517875 & -3.01755 & -5.689302 \\
\hline 5 & 759.0516 & 102.5864 & $1.01 \mathrm{E}-12$ & -7.861265 & -2.274655 & -5.591312 \\
\hline 6 & 826.7544 & $90.27045^{*}$ & $1.19 \mathrm{E}-13$ & -8.151232 & -1.478336 & -5.439899 \\
\hline \hline
\end{tabular}

Table no. 4 shows that VAR satisfies the stability condition.

\section{VAR's condition of stability}

\begin{tabular}{|l|l|}
\hline \multicolumn{1}{|c|}{ Root } & Modulus \\
\hline \hline & \\
\hline \hline 0.988132 & 0.988132 \\
\hline 0.9578 & 0.9578 \\
\hline 0.876513 & 0.876513 \\
\hline $0.711557-0.080754 \mathrm{i}$ & 0.716125 \\
\hline $0.711557+0.080754 \mathrm{i}$ & 0.716125 \\
\hline $0.292803-0.484830 \mathrm{i}$ & 0.566387 \\
\hline $0.292803+0.484830 \mathrm{i}$ & 0.566387 \\
\hline 0.398484 & 0.398484 \\
\hline-0.392834 & 0.392834 \\
\hline $0.301370-0.084827 \mathrm{i}$ & 0.313081 \\
\hline $0.301370+0.084827 \mathrm{i}$ & 0.313081 \\
\hline$-0.083738-0.219745 \mathrm{i}$ & 0.23516 \\
\hline$-0.083738+0.219745 \mathrm{i}$ & 0.23516 \\
\hline-0.01578 & 0.01578 \\
\hline \hline & \\
\hline \hline No root lies outside the unit circle. & \\
\hline \hline VAR satisfies the stability condition. & \\
\hline \hline
\end{tabular}

Table no. 4

From Table no. 5, which captures the results of Portmanteau autocorrelation test, it appears that there is a slightly autocorrelation for inferior lags which tends to decrease when increasing the number 
of lags. However, autocorrelation in models which point out the macroeconomic variables in panel type models is a common problem (Preinerstorfer and Potscher, 2013).

\section{Portmanteau Autocorrelation Test}

\begin{tabular}{|l|l|l|l|l|l|}
\hline $\begin{array}{l}\text { No. of } \\
\text { Lags }\end{array}$ & Q-Stat & Probability & Q-Stat Adjusted & Probability & df \\
\hline \hline \multicolumn{7}{|l|}{} \\
\hline \hline 1 & 8.326491 & NA* & 8.361773 & NA* & NA* $^{*}$ \\
\hline 2 & 46.94108 & NA* & 47.30499 & NA* & NA* \\
\hline 3 & 84.37445 & 0.0013 & 85.21828 & 0.0010 & 49 \\
\hline 4 & 128.2738 & 0.0217 & 129.8713 & 0.0172 & 98 \\
\hline 5 & 169.5808 & 0.0979 & 172.0685 & 0.0771 & 147 \\
\hline 6 & 225.3993 & 0.0736 & 229.3368 & 0.0516 & 196 \\
\hline 7 & 264.6198 & 0.1858 & 269.751 & 0.1330 & 245 \\
\hline 8 & 297.6357 & 0.4298 & 303.9203 & 0.3329 & 294 \\
\hline 9 & 320.5543 & 0.8026 & 327.7436 & 0.7142 & 343 \\
\hline 10 & 359.8364 & 0.8765 & 368.7562 & 0.7948 & 392 \\
\hline 11 & 419.2913 & 0.7645 & 431.1049 & 441 \\
\hline 12 & 553.7198 & 0.0242 & 572.7029 & 0.6229 \\
\hline \hline \multicolumn{7}{|l|}{} \\
\hline \hline$*$ The test is valid only for lags larger than the VAR lag order. \\
\hline \hline df is degrees of freedom for (approximate) chi-square distribution \\
\hline \hline
\end{tabular}

Heteroscedasticity test is presented in table. 6, proving that the null hypothesis, according to which the data are homoscedastic, is ruled out and our data are heteroscedastic, a fact commonly met in the type of panel models (Preinerstorfer, Potscher, 2013).

\section{Test of heteroscedasticity}

Table no.6.

\begin{tabular}{|l|l|l|}
\hline \multicolumn{2}{|c|}{ Joint test: } \\
\hline \hline Chi-sq & df & Prob. \\
\hline \hline 1346.477 & 812 & 0 \\
\hline
\end{tabular}

\section{Results and discussion}

Using the impulse response functions for the unrestricted VAR we have seen the influnce of the fiscal policy instruments' influence on the evolution of GDP. Therefore, the response of the evolution of GDP is analised based on the following graphs.

Considering the confindence intervals for the impulse response functions used below, we can say that the distance between them is larger due to the small number of observations. Narrowing the confidence intervals could be done by using the monthly observations, but unfortunatelly these monthly observations were not available for all the member states and for the period taken into 
consideration.

\section{Response of Gross Domestic Product to private consumption}

From this point on, we shall analyze the response of GDP to fiscal policy variables. In this respect, the chart no. 1 shows GDP response to an increase in private consumption, this being positive for the entire six years observation period. This is normal in our view, considering that private consumption in explaining more than $70 \%$ the evolution of GDP.

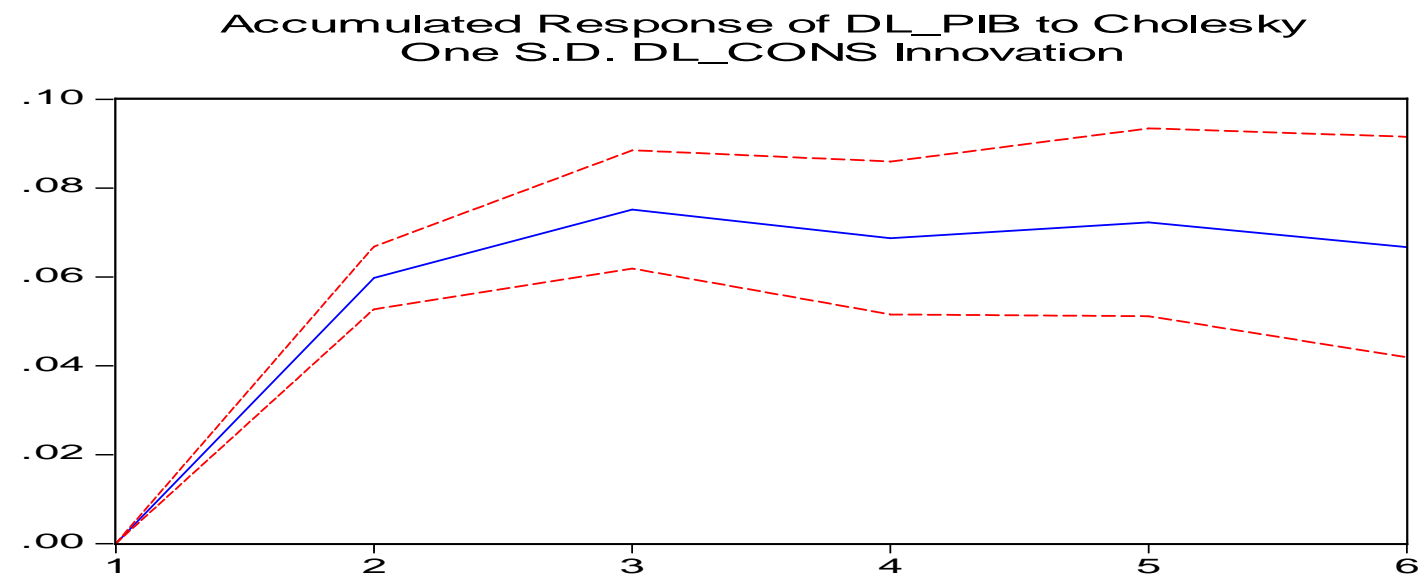

Chart no. 1 - GDP Response to private consumption

\section{Response of Gross Domestic Product to government spending}

It can be seen in chart no. 2 that an increase in government spending will have a positive impact on GDP in the first half of the observation period. Starting with the third year, the shock will be absorbed and the positive influence of this shock will change its meaning with the advent of the crowding-out phenomenon.

Accumulated Response of DL PIB to Cholesky One S.D. DL GOVEXP Innovation

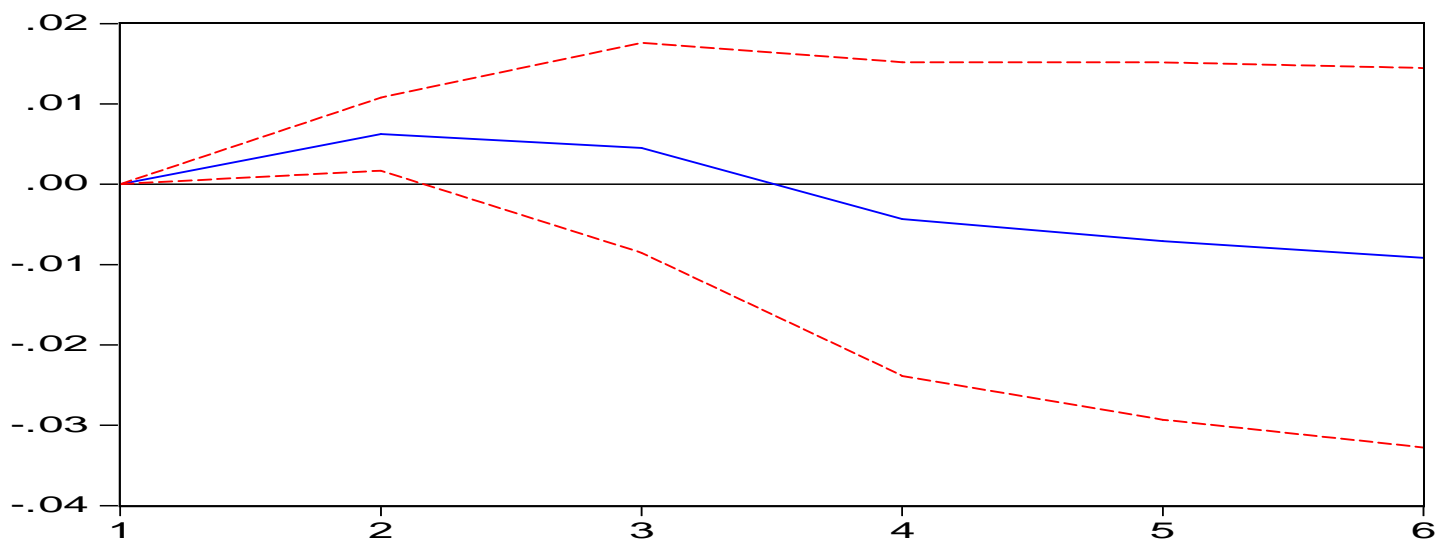

Chart no. 2 - GDP Response to government spending 


\section{Response of Gross Domestic Product to government debt}

From the chart no. 3 it can be noted that, throughout the period of observation, the influence of government debt is negative on the development of GDP. This can be explained by the influence of government debt on both private consumption and gross fixed capital formation. Both households and firms will slow down consumption and investment because in their rationally expectation scenarios, they will assume that a rise in the public debt will lead to an increase in the future tax rates.

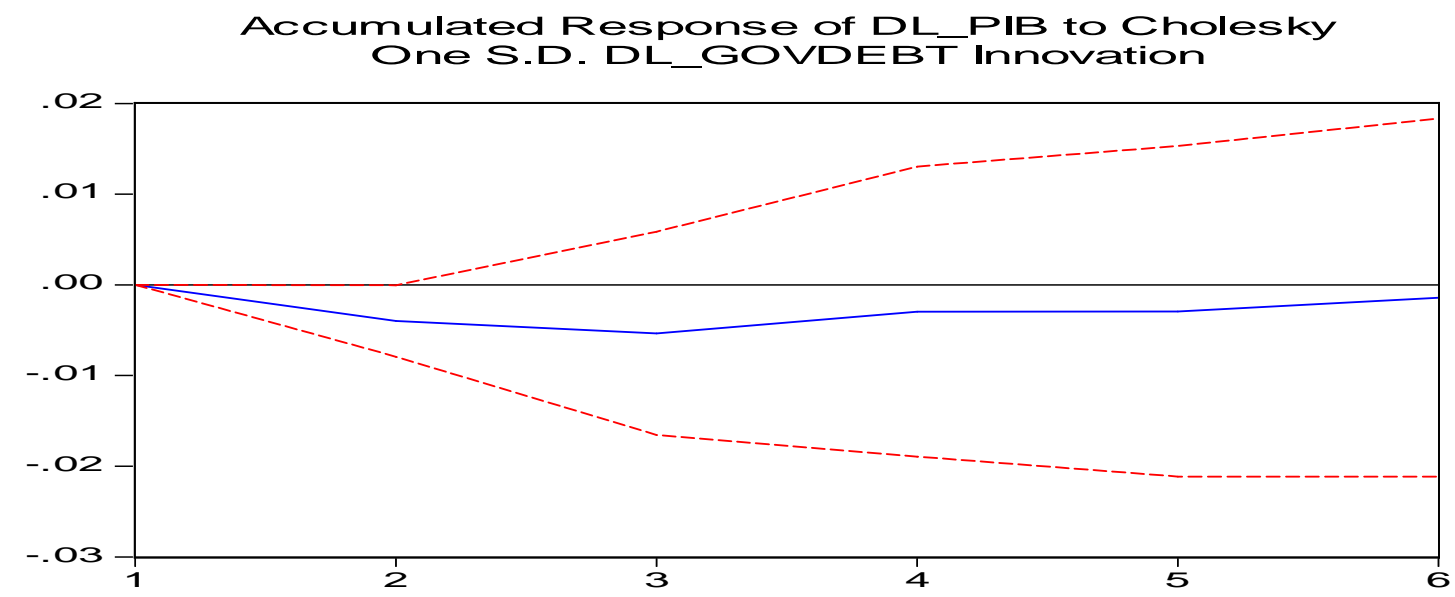

Chart no. 3 - GDP Response to government debt

\section{Response of Gross Domestic Product to interest rate}

We can observe from chart no. 4, that an increase in interest rates will have a negative impact on the GDP evolution because, in our opinion, it will increase the cost of lending and push the required rate of return to higher values. Thus, all the investments that were to be made between the old rate of return and the desired new one, determined by the new interest rate, will be abandoned.

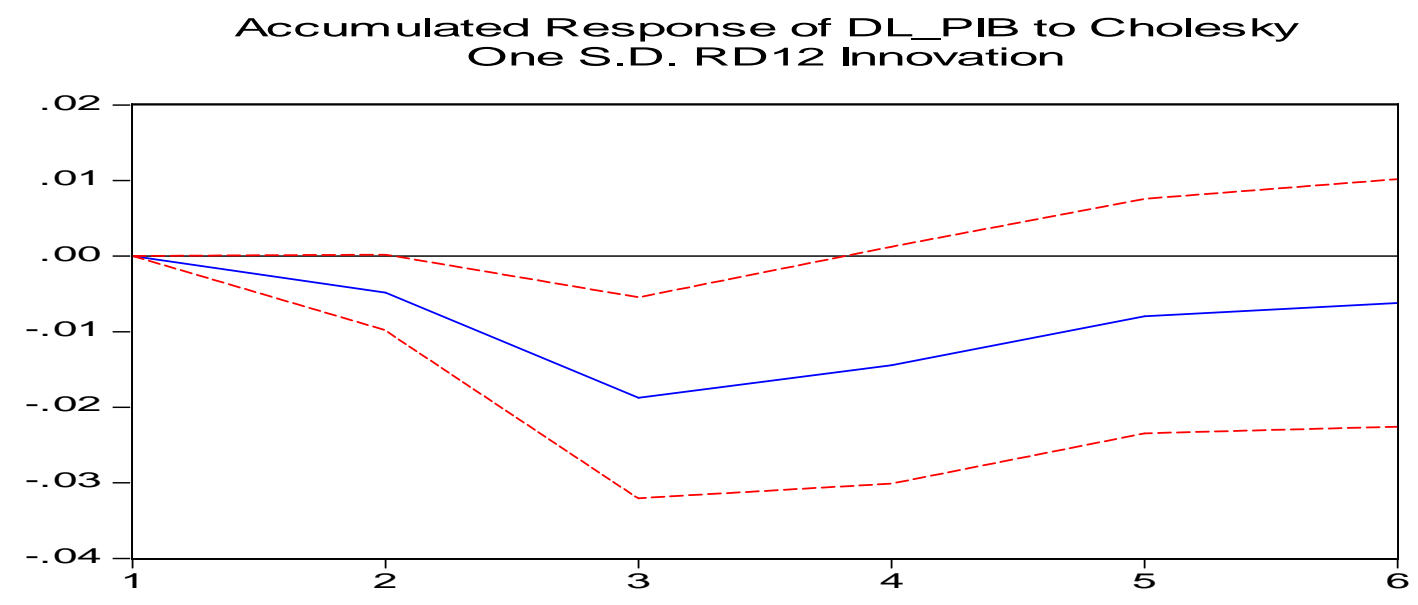

Chart no. 4 - GDP Response to Interest Rate 


\section{Response of Gross Domestic Product to inflation}

As we can observe from Chart no. 5 the influence of inflation rate on the development of GDP is positive, but this can also be explained by European central banks objective of maintaining the price stability. However, a rampant inflation growth can only have a negative influence on the GDP, as well as the deflationary phenomenon.

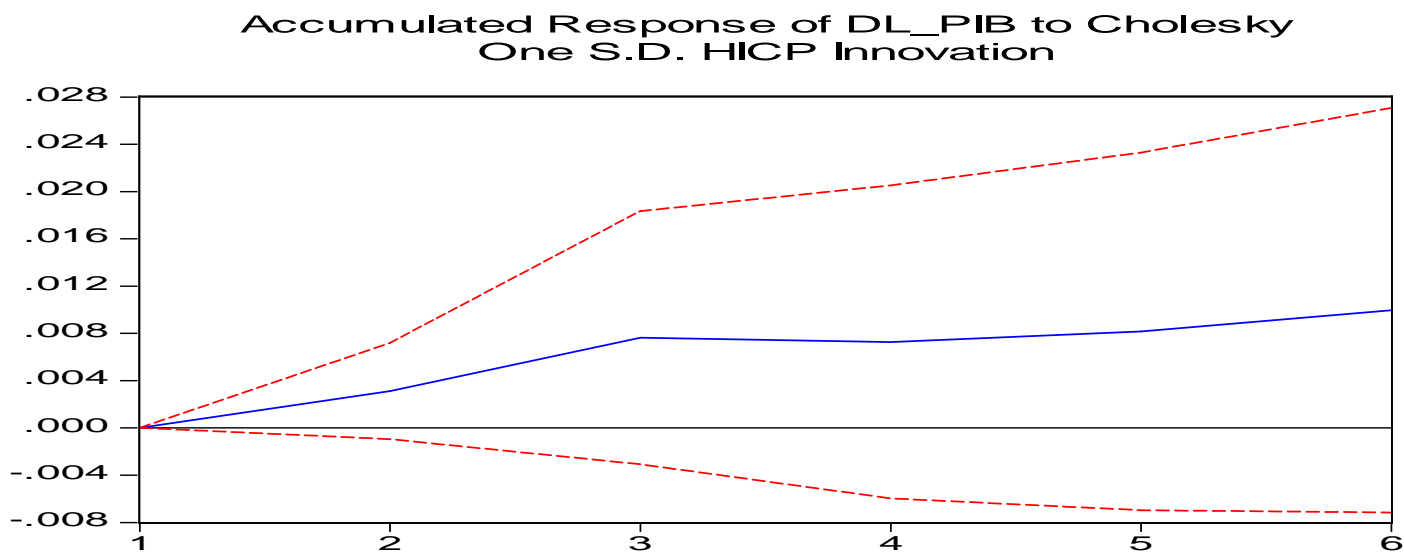

Chart no. 5 - GDP Response to inflation

6. Response of Gross Domestic Product to gross fixe capital formation

From the chart no. 6, the positive impact of investment on the development of GDP throughout the period of observation can be observed.

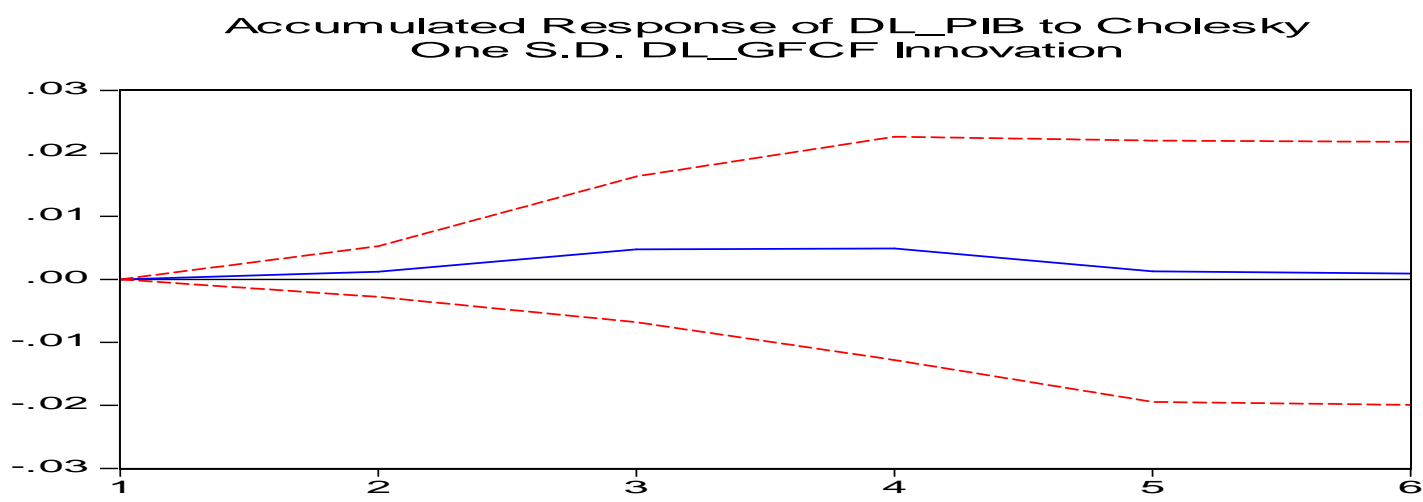

Chart no. 6 - GDP response to Gross fixed capital formation

Taking into consideration the results from the impulse response functions presented above, we can summarize the results in Table 7 as follows: 
Table no. 7.

Results obtained from our research

\begin{tabular}{|c|c|}
\hline Variables used & Results \\
\hline $\begin{array}{l}\text { GDP } \\
\text { Private consumption } \\
\text { Government expenditure; } \\
\text { Public debt; } \\
\text { Gross fix capital formation } \\
\text { Inflation } \\
\text { Interest rate }\end{array}$ & $\begin{array}{l}\text { Private consumption has a positive influence on the } \\
\text { evolution of GDP. This evolution in largely related to the } \\
\text { evolution of private consumption (as seen in table 6) } \\
\text { Public debt has a strong negative influence on the } \\
\text { evolution of GDP. } \\
\text { Government expenditure has a fluctuating influence on } \\
\text { GDP from positive to negative. } \\
\text { The increase in the level of interest rate has a strong } \\
\text { negative influence on the evolution of GDP. } \\
\text { An increase in the inflation rate has a positive influence } \\
\text { on GDP }\end{array}$ \\
\hline
\end{tabular}

Comparing the results obtained in our paper to the result obtained in the studied seen in Table no. 1, we can observe that firstly the public debt has a negative influence on the evolution of GDP, a common finding in the papers studied for our research. Secondly, the government expenditure is having a positive influence on GDP only for the first half of the observation period then turning negative. A possible explanation is that the positive shock from the increasing of the government spending is having on GDP is resorbed, then becoming negative. Another result that is worth mentioning is that the interest rate has a negative influence on the evolution of GDP, therefore, having a lower interest rate will stimulate investments because of a lower expected benefit ratio.

Table no. 8

GDP variance decomposition

\begin{tabular}{|l|l|l|l|l|l|l|l|l|}
\hline Period & S.E. & DL_GDP & DL_CONS & DL_GFCF & DL_GOVEXP & DL_GOVDEBT & RD12 & HICP \\
\hline \hline 1 & 0.027841 & 100 & 0 & 0 & 0 & 0 & 0 & 0 \\
\hline 2 & 0.068653 & 22.29417 & 75.80726 & 0.03212 & 0.825376 & 0.338859 & 0.49613 & 0.206085 \\
\hline 3 & 0.072109 & 20.54766 & 73.28588 & 0.268291 & 0.804757 & 0.342462 & 4.172649 & 0.578302 \\
\hline 4 & 0.073109 & 20.00224 & 72.07127 & 0.261392 & 2.252725 & 0.440034 & 4.407376 & 0.564964 \\
\hline 5 & 0.073637 & 19.74247 & 71.27172 & 0.500905 & 2.359777 & 0.433756 & 5.119608 & 0.571771 \\
\hline 6 & 0.073951 & 19.61366 & 71.23921 & 0.498761 & 2.418151 & 0.472078 & 5.132895 & 0.625241 \\
\hline \multicolumn{7}{|l|}{ Cholesky Ordering: DL_PIB DL_CONS DL_GFCF DL_GOVEXP DL_GOVDEBT RD12 HICP } \\
\hline \hline
\end{tabular}

We can see from Table no. 8, that shows the variance decomposition, that the GDP evolution is explained primarily by private consumption trends (over 70\%), than by the development of GDP in previous periods (20\%), followed by interest rate (4\%) and in a lesser degree, government spending (between 1 and 2.5\%). 


\section{Conclusions}

The main purpose of the paper was, using the unrestricted VAR, what are the fiscal policy instruments' implication and influence on the evolution of GDP. Therefore, not having in mind to exhaustive explain the fiscal policy implication on economic growth, we have obtained some results worth mentioning such as the influence of the public debt, of the government expenditure, private consumption and gross fixed capital formation on the evolution of GDP.

Therefore, government spending has an impact that fluctuates from positive, in the first half of the observation period, to negative, in the last part of it. Changes in this variables described above are scarcely explained by the evolution of government spending (2-3\%). Thus, we believe that an increase in government spending or public debt is not justified. Even thou we did not split the government consumption into productive and unproductive, we consider appropriate that productive government spending group should be at levels superior to those of nonproductive.

However, the rise in the public debt to unseen levels since the Second World War is a negative consequence of the financial and economic crisis that started in 2007. As we have shown in our research, it has a negative impact on the evolution of GDP, our reasoning is that the rise in public debt triggers a limitation of private consumption and investments based on the rational expectation of the populations that perceives this rise in the public debt as future increase in the level of taxes.

Based on the high percentage of private consumption that explains the evolution of GDP, we also consider that stimulating consumption is a treacherous path, since we have studied the EU 27 as a whole, not considering the imports and exports between EU member states. Considering this situation regarding that some EU member states are net importers, stimulating consumption will automatically increase the balance of trade deficit that will put more pressure on the exchange rate, not creating the premises of economic growth.

A stronger influence of interest rates on GDP evolution is presently observed. Consequently, the continued decline in interest rates during 2007 - present is an inspired choice, the challenge in this case being represented by the benchmark interest rates at levels that can not be reduced anymore. We also consider that a low inflation rate is desirable and is a "must-have" for sustainable growth.

After analyzing the impulse response functions afferent to the main variables of fiscal policy on gross domestic product in the case of EU member states, we conclude that the results obtained in our paper are similar to the specialized literature that we have studied.

These being said, we conclude that based on the results obtained in our research, we recommend a low inflation rate, with low interest rate doubled by an increase in productive government spending, where we also include allocations to the education, research and development sector, with expansionary austerity measures.

\section{References}

1. Afonso A., Sousa R., 2009. Fiscal policy and economic growth, BCE Working papers series.

2. Baum A., Koester G.B., 2011. The Impact of Fiscal Policy on Economic Activity over the Business Cycle - Evidence from a Threshold VAR Analysis, Discussion Paper Series 1: Economic Studies, No 03/2011

3. Beetsma R., Giuliodori M., Klaassen F., 2006. Trade Spill-overs of Fiscal Policy in the European Union: A Panel Analysis, Economic Policy.

4. Blanchard O., Perotti R., 2002. An empirical characterization of the dynamic effects of changes in government spending and taxes on output the Quarterly Journal of economics. 
5. Blankenau W., Simpson N., Tomljanovich M., 2004. Public education expenditures, taxation and growth: Linking data to theory, Journal of Development Economics.

6. Davig T., Leeper E., 2011. Monetary - fiscal policy interactions and fiscal stimulus, European Economic Review 55.

7. Durnecker G., Zagler M., 2003. Fiscal Policy And Economic Growth, Journal Of Economic Surveys Vol. 17, No. 3, Blackwell Publishing Ltd. 2003, 9600 Garsington Road, Oxford.

8. Fatás A., Mihov, I., 2003. The case for restricting fiscal policy discretion, - The Quarterly Journal of Economics.

9. Favero C., Giavazzi, F., 2007. Debt and the effects of fiscal policy, Econstor.

10. Perotti R., 2004. Estimating the effects of fiscal policy in OECD countries, Università Bocconi.

11. Preinerstorfer D., Potscher B., 2013. On Size and Power of Heteroscedasticity and Autocorrelation Robust Tests, Department of Statistics, University of Vienna.

12. Schaechter A., Kinda T., Budina N., Weber A., 2012. Fiscal Rules in Response to the Crisis Toward the "Next-Generation" Rules. A New Dataset, IMF Working Paper.

13. *** data taken from the Eurostat website. 